\title{
The Real Promise of Federalism: A Case Study of Arendt's International Thought
}

This is a post-peer-review, pre-copyedit version of an article

published in the European Journal of Political Theory.

Please do not quote from this version.

The final authenticated version is available online at:

https://doi.org/10.1177\%2F1474885120906059.

\author{
Shinkyu Lee \\ sk.james.lee@gmail.com
}

\begin{abstract}
For Hannah Arendt, the federal system is an effective mode of organizing different sources of power while avoiding sovereign politics. This article aims to contribute two specific claims to the burgeoning scholarship on Arendt's international federalism. First, Arendt's international thoughts call for balancing two demands: the domestic need for human greatness and flourishing and the international demand for regulation and cooperation. Second, her reflections on council-based federalism offer a nuanced position that views the dual elements of equality in politics (intra-state and inter-state equality) as neither contradictory nor reconciliatory but rather as ideal types along a continuum. This study shows that, through the unique form of federalism emphasizing the need to balance two demands of free politics with a clear acknowledgement of its precariousness, Arendt's thinking adds much-needed sensitivity to international discourse.
\end{abstract}

\section{Keywords}

Arendt, federalism, freedom, sovereignty, representation, state agency

\section{Acknowledgements}

An earlier version of this article was presented to the Theorizing International and Global Society panel at the 2019 convention of the International Studies Association in Toronto. I thank fellow panelists April Biccum, Tristen Naylor, Kilian Spandler, and Matthew Weinert and the discussant Lisa Samuel for their inspiration and comments. I am also grateful to Dana Villa, Catherine Zuckert, and Ernesto Verdeja for their encouragement and critiques regarding the basic ideas on Arendt's federalism displayed in this paper. Finally, I thank the EJPT editorial team along with the two anonymous reviewers for their valuable guidance and suggestions. 
Hannah Arendt (1993: 146) famously argued that whereas freedom-“the raison d'etre of politics"- can only be achieved via acting together, the sovereign will is always unitary and negates plurality, the precondition of free politics. Further, she stated (1993: 165), "If men wish to be free, it is precisely sovereignty they must renounce." The anti-sovereign aspect of Arendt's thought appeals to critical theories of international relations that problematize the mainstream scholarship building on the principles of state sovereignty and international anarchy. ${ }^{1}$ Of course, Arendt's thinking has distinctive features that do not conform so easily to those alternative theories. For example, although Karl Marx's thoughts constitute a crucial source of inspiration for critical international theories, Arendt (1998: 116, 228) considers Marx's arguments too deterministic to fit her free politics, as several scholars (Canovan, 1992: 63-98; Weisman, 2013; cf. Barbour, 2014) point out. We must also note that, though fiercely resistant to establishing politics in natural and quasi-natural criteria, Arendt (1998: 50-58) emphasizes a politically engaged care for the world in which individuals act and attain their public identities. By highlighting a rootedness solidified through public remembrance and organized communities, Arendt's thinking differs from the poststructuralist rendition of subjectivity in which individuals have no agency for their identity construction (Hyvönen, 2016: 201-205; Lang, 2005: 223; Villa, 1992). That said, Arendt would undoubtedly find problematic the overly deterministic aspect of mainstream international theories arguing that no central authority exists among sovereign states and that this immutable anarchic status of international politics brings states into constant security competition (Baehr, 2010: 14-26; Barder and McCourt, 2010; Williams, 2005: 6). Indeed, a recent trend in Arendt studies is to engage in this

\footnotetext{
${ }^{1}$ I use "critical theory" as an umbrella term to refer to alternative theories of international relations, within which four core stands exist: Frankfurt School critical theory, neo-Gramscian theory, feminism, and post-structuralism (Rengger and Thirkell-White, 2007: 5-10).
} 
promising area where her thinking aligns with critiques of the assumptions of mainstream international theories. Grounded in Arendt's critique of sovereignty, violence, and domination, several works have fruitfully applied her free politics to the global dimension of politics (e.g. Axtmann, 2006; Hayden, 2009; Owens, 2007).

Less explored, however, is Arendt's discussion of federalism, a mode of political organization that divides powers between two or more institutional levels of government. It is not the only way to separate power; confederalism and devolution also divide powers. Yet, federalism is distinctive as a middle way, pursuing more or less integration between the general and regional levels of government than confederalism and devolution, respectively (Hueglin and Fenna, 2005: 31). Arendt (2006: 141) also recognizes that "the separation or the balance of powers" is federalism's function. The federated republic, Arendt (2006: 142) believes, eschews the possibility that powers at the local level of politics will be destroyed or "result in a decrease of [their] potency" through tyrannies or excessive legalism. At the same time, her federalism resists any approach that renders the power of the central government non-existent because, without a viable central government, "the allied powers" of the local units "cancel one another out" (Arendt, 2006: 144). In Arendt's (2006: 166, 1970: 44) view, power emerges from people acting in concert and the federal system is an effective mode of organization for associating different sources of power. In federation, "neither expansion nor conquest but the further combination of powers" happens (Arendt, 2006: 159). Arendt (2006: 144) claims that federalism avoids the centralization of power and contributes to the abolition of sovereignty. If federalism is a central element in Arendt's thoughts regarding how to associate powers while avoiding sovereign politics, delving into her views on federation is necessary to any presentation of her free politics at the international level. To date, however, a systematic analysis in this regard is wanting. In the pioneering works applying Arendt's thinking to 
international politics, her views on federalism only constitute a small segment (Axtmann, 2006: 107; Hayden, 2009: 26; Owens, 2007: 145). Recent engagement with Arendt's accounts of federation and the role of councils in her thinking is inspiring, but its discussion of international federalism is rather sporadic (Ashcroft, 2015: 436; Lederman, 2019: 30; Selinger, 2016: 418). Certainly, several attempts to relate Arendt's thoughts to supranational institutions such as the European Union exist (Benhabib, 2006: 13-80; Rensmann, 2019; Verovšek, 2014: 403-410). Yet, as Douglas Klusmeyer (2009: 51) notes, Arendt's reluctance to spell out a clear model of international federation has a special meaning in her political thoughts. Her real intent becomes clear when we identify and address the crucial questions her federalism raises: What is the unit of federation? Are all units of federation or sites of power equal? Or, does Arendt's federal system operate on two separate tracks: domestic and global federations? How are the lower and higher councils in the federal system Arendt envisions connected?

This article attends to issues regarding federation's unit and scale that Arendt's writings generate. Using her federalism as a case study to examine her international thought, I show that her thinking is dualistic in nature. Arendt approves of neither authoritarianism nor imperialism, and her council-based federalism is a refined program that helps us avoid those two dangers free politics encounters. In the end, though, Arendt leaves inconclusive her views on some specific areas of international politics to which her federalism can be extended. Such ambiguity is closely associated with her acute recognition of the difficulty in balancing intrastate and inter-state equality for free politics.

Beyond Arendt studies, the paper engages with contemporary scholarship on international federalism. Federalism has been a contentious issue in international relations. For some, a prime example of federalism that challenges the form of state relations dictated by the anarchic Westphalian system is the Philadelphia System of the American States Union of 1787- 
1861 (e.g. Deudney, 1995: 201). The Philadelphian model is applicable to the global scale of politics because the technological development of modern weaponry, such as nuclear weapons, prompts states to consider the cost of their violent competition. This change in the material contexts of violence motivates states to revamp their extant security arrangements, alternatively creating a "federal-republican world nuclear government" (Deudney, 2007: 162). Sharing the broad insight into federalism as a middle way that avoids both international hierarchy and anarchy, other scholars explore its specific value in international law (e.g. Cohen, 2012: 80-158). The argument is that the legal order federalism envisions eschews abuses of power in both global and domestic orders, to which other forms of power separation at the international level, such as global constitutionalism and legal pluralism, are vulnerable, respectively. $^{2}$

The burgeoning scholarship on international federalism can greatly benefit from Arendt's insights. As this paper will detail, Arendt's thinking, by associating federalism with her action-driven free politics, urges security theorists to revisit their material base for federation and, with her radical critique of sovereignty, directs international law scholars' attention to the danger of entertaining the idea of sovereign and reified states in federation.

\section{The federal system: Neither from above nor from below}

As noted, Arendt thinks the federated republic abolishes sovereignty. Broadly, sovereignty refers to the supreme authority of a governing body over itself. In state politics, sovereignty entails two claims: the state is the supreme authority within its territory over its inhabitants,

\footnotetext{
${ }^{2}$ Contra legal pluralism, global constitutionalism argues that "[states'] legal systems have their conditions of validity ... in the higher, supreme, autonomous international legal order" (Cohen, 2012: 48). The intricate question of international legal order's source aside, however, constructing a less rigid form of global constitutionalism is not impossible (Lang, 2013: 114-115).
} 
and it is autonomous from outside powers. To Arendt, the discourse of sovereignty, which assumes the presence and necessity of a commander with ultimate discretion of power, takes the form of rule and domination. It is thus anti-political, contradicting her idea of free politics, which occurs through talks and mutual deliberation among diverse equals. Arendt (2006: 143) understands that the federated system associates multiple sites of power and eschews power's concentration in a single sovereign source.

But, what concerns us here is whether and how such a federalist vision of Arendt's free politics applies to international politics. Fundamental to Arendt's international thinking is that she approves of neither the sovereign state system nor the world state. On one hand, Arendt is greatly troubled by state sovereignty and its effect on warfare. Knowing the decolonization struggles of the 1960s, Arendt (1970: 5) expresses her anxiety about the development that "national independence, namely, freedom from foreign rule, and the sovereignty of the state, namely, the claim to unchecked and unlimited power in foreign affairs, are identified." On the other hand, Arendt worries that institutionalizing the vision of cosmopolitan oneness could lead to world tyranny. To Arendt (1972: 230), "[the] world government ... could easily become the most frightful tyranny conceivable, since from its global police force there would be no escape-until it finally fell apart." It is interesting that when opposing a world government, Arendt does not invoke individuals or communities. Arendt's (1968: 81) statement that the world state is a sovereign entity that is "unchecked and uncontrolled by other sovereign powers" indicates that in resisting the rise of world state, she sees a functional value of the pluralistic orders states constitute.

Does Arendt believe federalism should extend to international politics? As Arendt's (1968: 93) account of "a world-wide federated structure" attests, her answer is affirmative. This wording, however, appears in a short essay and only raises further questions, such as what 
the basic unit of world federation is. Several works in intellectual history highlight Arendt's early writings on postwar European reconstruction and Israel-Palestine relations to provide more substance on this topic. William Selinger (2016: 421-431), for instance, observes that Arendt's writings in the 1940s, though supportive of a European federation, suggest that its base lie in nationalities, not individuals. Driving this federalism is Arendt's (2007: 130) belief that within a federal structure of European nations with its own parliament, Jews can be recognized and represented as a nation. Grounded in the nation-based federation, Arendt also considers the Jewish-Arab question in Palestine. Rather than advocating for a national Jewish state in Palestine, Arendt (2007: 197) envisions integrating the region into a much larger federation, such that a federation in Palestine is part of higher federations in the Middle East, the Mediterranean region, and even Europe. Arendt (2007: 196) expects that once both Jews and Arabs enjoy equal rights as members of a larger system, deciding a ruler over Palestine will become unnecessary.

Of course, presenting an Arendtian federalism that is congenial to nationalities needs qualification. For one, the nation operative in Arendt's federalism is not territorial (Selinger, 2016: 424). To Arendt (1994: 210), “[w]ithin federated structures, nationality would become a personal status rather than a territorial one." In addition, the nation Arendt has in mind relies on a shared past or "organized remembrance" primarily conceived of as "the beginning of identity for individuals within that tradition and, from this, the loose, changing basis of national identity" (Ashcroft, 2017: 444). Thus, the principle of plurality that denies a definite center of power should be effective at both the national and the individual levels of politics. Finally, Arendt's federalism concerns not merely the external federation of states or nations but also their internal federalization (Lederman, 2019: 13). This is evident when Arendt (1994: 114, also 2007: 400) applauds the French resistance movements which recognize that "a 
federative structure of Europe must be based on similarly federated structures in the constituent states." For Arendt (1972: 231-233), a good candidate for the small units of such internal federalization is federated grassroots councils.

These interpretations about Arendt's early writings bring needed clarity to the "some kind of organized community" Arendt (1973: 294) considers for free politics. However, they still face the core issue that arises when one makes a case for Arendt's international federalism. Territorial or not, an Arendtian political community encounters the question of whether and how it can pursue action and freedom in intra-polity and inter-polity relations to the same degree simultaneously (Lee, 2020: 5-10). True, the principle of plurality must apply to all levels of Arendt's free politics (Ashcroft, 2017: 448). But, for Arendt, plurality exists as a condition for action. Our questions, then, need to be more specific: Who is the constitutive actor in Arendt's international federalism? Two types of actor, collective and individual, are conceivable in this context. Arendt's council model mitigates their possible conflict by seeking internal federalization. Yet, as detailed below, it cannot avoid the challenge representation creates.

To further articulate a form of political community Arendt's federalism implies, the remainder of this section discusses state agency, or the scope of states' ability to engage with each other. This analysis is a preliminary step for the later examination of Arendt's intended ambiguity in some of the areas of international federalism.

Saying that Arendt entrusts the state with a degree of agency may be absurd. But, Arendt's (1973: 275) appreciation of the constitutional state, along with her qualified endorsement of nationality for federalism noted above, suggests that state agency is not irrelevant to Arendt. In fact, the question of state agency comes to the fore when Arendt formulates a new concept of the state. In her interview conducted in 1970 and published later 
as "Thoughts on Politics and Revolution," Arendt argues that the rudiments of that innovative idea are found in the federal system. Drawing attention to what she describes in On Revolution as the federation model's advantage over the sovereign nation, Arendt (1972: 230) claims that federalism allows for a situation in which "power moves neither from above nor from below, but is horizontally directed so that the federated units mutually check and control their powers." To Arendt, then, federalism facilitates two features of free politics. First, the federal system resists the power imposed from above on the people. In the international context, power "from above" points to world government. Thus, in her specific reference to federalism during the interview, Arendt confirms that the new order of the world ought to be international rather than supernational. That is, we need not install a single hegemonic power to enforce a new order for the whole world but instead cultivate a space for mutual deliberation among states. Federalism, for Arendt, is an effective method for working toward such a goal. However, Arendt also argues that the federal system avoids power moving "from below." By this, Arendt is not denying the importance of local agency in politics. The situation Arendt considers here is that the source of power solely lies in each sovereign state-leading to constant interstate competition for security.

In Arendt's view, federalism is essential for envisaging a new order of world politics because it shifts attention to the international dimension in between states from both "power from the above" and "power from the below." Arendt's genuine appreciation of this merit of federalism is implied when she asks, "Where do we find models that could help us in construing, at least theoretically, an international authority as the highest control agency?” (1972: 231). Objecting to both world tyranny and international anarchy, Arendt highlights the importance of securing a space where states can continue sharing diverse opinions regarding world affairs. For this, she finds it crucial that we first revisit our assumption that what is 
highest always has to be sovereign. To Arendt, the highest authority in world politics should be found in between states, and federalism is best able to actualize this idea.

However, to what extent the state has agency in international affairs is unclear. If the highest authority in world politics is conceived of as being between states and derivative of their agreements, this in effect assumes that the actor in question is a state. But, if a state is free to make decisions as a constitutive actor of international politics, does this not affect the agency of the people it represents? In fact, how to attend to the "structural" dimension of the state while keeping individual citizens' agency intact is highly contested in the contemporary scholarship of international relations (Jackson, 2004: 285; Miller, 2016: 223-226; Wight, 2004), and Arendt's statement about federalism's relationship to state agency is rather ambiguous. In response to this charge, one may contend that overall, Arendt's thinking strongly suggests she fundamentally disagrees with any type of statism and that Arendt would even assure us that the real actors in international terrain ought to be individual persons, not states. If we follow this line of interpretation, it does appear that the best form of democratic engagement matching Arendt's vision of free politics in world politics is something like "global social movements" (Kaldor, 2013; Smith, 2007).

Certainly, many of Arendt's works indicate her great problems with sovereign statism. Indeed, the Rousseauian state uniting citizens in a single General Will is a nightmare to Arendt's vision of free politics (Canovan, 1983; Volk, 2015: 67-92). Yet, Arendt (1968: 81-82, 1973: 267-302,2006: 267) still considers the state an extremely important facilitator of freedom and action, not only because the state is the second-best option for avoiding statelessnessthe most extreme form of vulnerability — but also because it provides stability for politics and eventually fosters public culture and civilization. Arendt (2006: 148) articulates this point well in On Revolution, arguing that a constitution is "an endurable objective thing," rather than the 
product of a constitutive will. Separated from the ever-changing will or moods of a multitude, the constitutional state secures stability and goes through gradual modifications in accordance with changing circumstances (2006: 216). Only through such "a lasting institution" does Arendt (1998: 197, 2006: 221) think human beings can achieve the greatness of public culture and civilization, as they eschew the difficulty of "establish[ing] together the everlasting remembrance of their good and bad deeds, to inspire admiration in the present and in future ages." Arendt's broad point here is that, owing to such an internal demand for stability and continuity for human greatness, the constitutional state has an independent dimension once it is created and put in (federal) relationship with other states (Canovan, 1996: 18; Villa, 2008: 250; Waldron, 2000).

Back to the question of how to construct "an international authority," we find an unresolved issue regarding state agency. Arendt urges us to explore the international "inbetween," where plural states—rather than one hegemonic supranational entity-continue sharing their different views and achieve a (fragile) consensus. This sensible suggestion, however, leads us to question the merits and challenges associated with treating the state as a "living" actor in reaching international agreements. The concern about such an emphasis on "state personhood" (Wendt, 2004: 293-295) is that it increases the possibility that the state as an actor in the international domain will pursue its collective interest, which may not always be compatible with the interests of individual citizens or sub-communities of the state.

\section{The council system for federations}

Arendt's discussion of the council system right after international authority in the interview in question suggests that she considers it an essential component for restructuring international politics. We have confirmed that Arendt had a deep interest in the council system early on. As 
recent careful studies demonstrate, her federalist thinking is inseparable from the rich tradition of the council system (Lederman, 2019: 171-197; Muldoon, 2016). The radical call for internal federalization, which Arendt notes was vivid among some of the grassroots movements influenced by that tradition, is particularly relevant to an investigation of Arendt's international federalism. But, for the actual implementation of this desire in international politics, the specific status of councils in federation needs to be clear. Are all units of federation or all layers of councils equal? Does a local council stand alone or play a supplementary role for higher institutions?

The council system, according to Arendt, is based on some of the experiences of modern revolution. Although her account of the council model in the 1970 interview is brief, she provides a fuller explanation in other places. For instance, in the article titled "Totalitarian Imperialism," Arendt (1958: 32) recounts how, in the Hungarian Revolution, the councilsthe lower councils in the provinces, the higher councils, and the Supreme Council—quickly and effectively formed a complex system of coordination at multiple levels of politics. The accuracy of Arendt's descriptions of councils aside (Muldoon, 2016: 785), the Hungarian Revolution evidently reinforced her belief in council-based federation, and Arendt (2006: 270) later incorporates this observation into her major work, On Revolution:

[T] he men who sat in the councils were also an elite, they were even the only political elite, of the people and sprung from the people, the modern world has ever seen, but they were not nominated from above and not supported from below. ... From these "elementary republics," the councilmen then chose their deputies for the next higher council, and these deputies, again, were selected by their peers, they were not subject to any pressure either from above or from below. Their title rested on nothing but the confidence of their equals... Once elected and sent in the next higher council, the deputy found himself again among his peers, for the deputies on any given level in this system were those who had received a special trust. 
Similar to her claim that federalism avoids power from both above and below, Arendt here argues that the council system depends on neither an order from above nor a demand from below. Arendt wants to show how the council system eschews the command-obedience or top-down model of politics. She acknowledges that the delegation process in the council system renders it pyramidal. But, for Arendt, the council system is not authoritarian because public deliberation among equals, as well as their mutual confidence, is decisive in it. Hence, Arendt (2006: 270) asserts that "while, in all authoritarian government we know of, authority is filtered down from above, in this case authority [is] generated neither at the top nor at the bottom, but on each of the pyramid's layers."

This voluntary system of coordination at multiple levels of council politics must have affected Arendt's judgment that the council system helps us form a new concept of the state. In Arendt's (1972: 233) words, "[a] council-state of this sort, to which the principle of sovereignty would be wholly alien, would be admirably suited to federations of the most various kinds, especially because in it power would be constituted horizontally and not vertically." However, as was her account of federalism, this statement is incomplete. It only claims that a state's being reconstructed to accommodate the multiple sites of power the council model fosters greatly facilitates federation. Federation can happen in either of two directions. In one, different political communities are federated within the boundaries of the same state. In the other, a worldwide federation is composed of different states, each of which has an independent legal and political order. Arendt's accounts do not specify if and how the new state reconstructed via the council system facilitates these two (not necessarily complementary) demands of federation to the same degree simultaneously. ${ }^{3}$

\footnotetext{
3 As Lederman (2019: 18) points out, Arendt's interest in both international and domestic federations is a distinctive aspect of her thinking. Yet, her accounts of the council state do not specify how such
} 
Facing Arendt's ambivalence, one may argue that her council-based federalism has no real implications for international politics because "from the external standpoint there is not the difference that [Arendt] sometimes imagined between federal republics and nation-states" (Arato and Cohen, 2010: 162). This interpretation renders Arendt's thoughts closer to the Waltzian theory of international politics that treats states as identical; how the state is internally constituted does not really matter (Waltz, 1979). Arendt's theory of political association is far from this. On Revolution, among others, demonstrates how her constitutionalism integrates new voices for change into constitutional amendments as a way of augmentation through which people actively apply and expand constitutional principles in their public lives and incrementally modify the existing arrangements of public judgement (Arendt, 2006: 192-206, 219-221). If the constitutional state's internal arrangement changes, the existing stipulations regarding the state's external relations with other states will not remain intact. Thus, the implications of Arendt's theory go well beyond the domestic affairs of political community.

Another way of dealing with Arendt's ambiguity is to argue that she treats all units of federation (such as individuals, groups, and states) as equal narratives that are constantly connected and reconnected through storytelling across the sites of their origins (Benhabib, 2007: 454-456, 2009: 697-699). This interpretation is plausible, if not free from interpretive problems. The relational dimension of storytelling comes to the fore when Arendt articulates her theory of action. For her, action and speech produce stories when inserted into a web of human relationships. Arendt (1998: 50, 184, 190) famously describes such a mutually constituted aspect of action-driven politics by stating that we become both "actors" and "sufferers" through storytelling. This rendition of Arendt's thinking seems quite compatible

a concomitant federation occurs. This is particularly so, as detailed below, when we examine her council-state with regard to the two demands of equality for free politics. 
with narrative theories of international relations that accentuate the intersubjective dimension of state actors (Neumann, 2004; Ringmar, 1996; Weber, 1998).

However, two aspects of the council system in Arendt's thinking challenge the narrativist interpretation. First, Arendt's statements about the council system suggest that the council goes through a delegation process. Since this creates different levels in the system, Arendt's council-based federalism does not easily fit with any position that treats all units of federation as nominal. In addition, for Arendt, a delegation in the council system has an ending point. Her accounts suggest that people at the grassroots level volunteer to create a council and that peers in such an elementary council select their deputies for the next higher council. Does this delegation work in such a back-and-forth way across the different levels of the council system? Arendt would say no. According to her, the council system forms a pyramid, even though it differs from the typical authoritarian government. A pyramidal government based on the council system implies that a highest level of delegation exists. Arendt's councilbased politics, then, has a certain end point; that is, it is not characterized by an endless backand-forth exchange of individual narratives.

As such, Arendt's ambiguity persists. This becomes even clearer when we ask what the end point in the council system is. Does the delegation process end at the state level? Or, do the deputies at the level of the constitutional state select another group for the next council at the global level? If we assume that the council model extends to the global level, where all representatives of different states come together, the burden of representation becomes heavy. The deputies sent to the global council have to represent the already diverse opinions of their states. In a sense, this issue should not trouble Arendt's council-based politics because she is clear that the council system's authority comes from neither above nor below. Yet, the 
problem of how to represent internal diversity will truly disappear only if the higher level of politics is completely disconnected from the views from below.

This detachment from the base of politics is not Arendt's preference. When she deals with the council system, Arendt does not want to abandon the "bottom-up" approach fostering public deliberation at the grassroots level that crystalizes her republicanism. ${ }^{4}$ By her remark of "not from below," Arendt (2006: 270) means that independence exists in "each of the pyramid's layers [of the council system].” From this multi-layered source of power, we can see that Arendt's council-based politics significantly reduces the problem of representation when compared to the central sovereign politics model. However, this problem does not disappear to the extent that the deputies at the global council are released from the obligation to reflect the opinions of the people they represent, nor will opinions and narratives at the local level of the council system always be smoothly and harmoniously exchanged with those at the global level of the system.

Against this interpretation accentuating Arendt's ambiguity, one may contend that for Arendt, the council system is based on mutual trust and that trust among individuals of the council system serves to fill the gaps between the system's different layers. Arendt (1958: 30, 2006: 270) does describe deputies as receiving "a special trust" from the peers who selected them. But, much caution is required in handling this term for our context. A special trust from his people does not mean that the deputy is free to do whatever he wants at the next council. He is still responsible to represent the people who have selected him. In addition, we must consider the complexity associated with the increasingly expansive burden of representation as the delegation process goes up to higher levels. Is the range of representation at the city

\footnotetext{
${ }^{4}$ For further articulation of Arendt's "bottom-up" approach and her insight into local agency, see Lee (2020).
} 
council the same as that at the province or state council? The latter must be more expansive than the former with regard to the range of diversity it can accommodate.

When Arendt emphasizes the autonomy of each layer of the council system, her target of critique is the top-down model of politics. Yet, although her resistance to the commandobedience view of politics via council-based federalism is clear and insightful, we are left with the question of how the deputies at different levels of the council system are connected. Arendt (2006: 270) herself only confirms that the deputies "rested on nothing but the confidence of their equals." Equals here can indicate equality between the deputy and either the people who select him or other deputies who meet him at the higher council. Arendt's point may be that confidence exists in both cases. However, she does not clarify "the relationship between the delegates of the lower and those of the higher councils" (Kalyvas, 2008: 280). All we have here are two cases that are not necessarily the same: the people's confidence in their deputy that he is "best suited to present [their] view before the next higher council" (Arendt, 1972: 233) and other deputies' confidence in the deputy in question as a conversational working partner.

As their actual objects of confidence are not identical, we should not mingle these two cases. Doing so not only obscures the very possibility of conflict between these different sources of confidence but also fails to capture the real meaning of Arendt's ambiguity in her formulation of a new state via the council system. Indeed, such conflict is most probable in the context of international politics, as the deputy in question would be torn between the trust that comes from the people who selected him as their state representative and the confidence that other deputies at the global council meeting who are responsible for representing their own people's views place in him as a competent diplomatic partner. 
Thus, Arendt's council-based federalism leaves inconclusive some of the points pertinent to international politics. Arendt surely considers council-based federalism effective for achieving her free politics. This belief is undergirded by her judgments that for freedom to exist as "a tangible reality," a spatial limit should exist and that the bounded public space is not singular; there can be many public spaces for freedom (2006: 267, 232). Still, for Arendt (2006: 270), these public spaces are not scattered but can form a pyramidal structure through the delegation process. Such a council-based politics, while providing autonomy at each level of delegation, significantly departs from the sovereign state model that subjects all power sources to a central sovereign entity. However, Arendt's council model does not specify the relationship between the higher and lower levels of councils. This ambiguity, as I have suggested, closely relates to Arendt's recognition of a difficult issue her council-based federalism raises for international politics: How much autonomy does the delegate of the state have as a diplomatic actor in the international scene as he balances representing his people with being a working partner of the delegates from other states?

\section{Cosmopolitan and communitarian variants of federalism}

Behind Arendt's lack of clarity in her statements about the federal/council system lies a broad issue of state agency. In general, two areas of concern exist with regard to maintaining state agency: inter-state equality and intra-state equality. Arendt's council-based federalism suggests her awareness that together, these two demands complicate international federalism.

As noted earlier, Arendt sees that creating an international authority in between states would have the positive effect of resisting the rise of global hegemony or world tyranny. Yet, for all states to be treated as equal and international authority to be based on their agreement, the main actor in question must be the state. Here, the problem of representation appears 
because individuals and groups may not always find their interests compatible with the state's collective interest. From Arendt's perspective, however, the opposite argument is not palatable either. Although the idea of equal individuals all around the world achieving a true democracy is appealing, politics needs structures and institutions that provide stability and continuity for human greatness and flourishing; thus, states should secure some independent dimension once they are created. Besides, if states have no agency in the international domain, there will be no collective entity responsible for an event like war (Lang, 2002). This would make diplomacy ineffective and render international negotiation difficult. Arendt's council-based federalism, as we have seen, is a case in point revealing the complexity in her thoughts on these two aspects of state agency.

The two cases of equality (about the inter-state and intra-state dimensions of state politics) relate to contemporary international discourse driven by responses to imperialism and authoritarianism. If imperialism is the worst kind of inter-state inequality, authoritarianism is the worst type of intra-state inequality. And, one can say that cosmopolitanism argues for antiauthoritarianism and that a communitarian version of political discourse in international politics promotes anti-imperialism. Distinctive in Arendt's federalism is that while it clearly pursues a middle way in international discourse, it also resists any attempts to fully resolve the tension between the two competing demands for intra-state and inter-state equality. Cognizant of the complex nature of the issue and the highly contingent character of practical politics, Arendt never offers a clear-cut solution to this murky area of international discourse. This approach can frustrate theorists pursuing a clear model of politics, but the ambivalent aspect of Arendt's council-based federalism helps it reflect the complexity and dynamism of the real world of politics. 
The distinctive aspect of Arendt's federalism becomes clearer when her thinking is compared with other theories of federation. For example, Seyla Benhabib's and Jean Cohen's recent works on federalism suggest their respective departures from Arendt's own federalism. Their works acutely demonstrate the dangers the construction of a middle ground for international politics encounters and the importance of acknowledging the challenge of balancing the demands for intra-state and inter-state equality.

Benhabib (2004a: 115) attributes the ambiguity found in Arendt's international arguments to the conflict between her republican approach and her inchoate Kantianism. As an alternative, Benhabib notes that cosmopolitan norms can be reconciled with republican principles of self-determination. Thus, her "cosmopolitan federalism" presents itself as bridging the familiar gap between the universal and the particular or the global and the local (2004b: 171-221). The problem is that this promise of reconciliation tends to privilege cosmopolitan norms, as Benhabib conflates the moral and the political.

Benhabib (2009: 692) emphasizes that her position differs from that of the global constitutionalists who, in her view, fail to see the importance of "local contextualization, interpretation, and vernacularization [of cosmopolitan norms] by self-governing peoples.” Her interest in localness is in line with her view that critical theory should be "a critical theory of the present" (2014: 710). Still, her call for critical realism comes with a theory construction that is not entirely uncontroversial because she treats the general (moral) association as the local where it should be a particular political community. There is not necessarily continuity between them, however. As Hans Lindahl (2009: 420) observes, the difference is that "[m]oral norms speak to reciprocity between individuals as human beings, regardless of their political affiliation; by contrast, legally binding and enforceable norms ultimately presuppose political reciprocity." Of the two discrete kinds of association, what concerns us as the local is not really 
about an association in general but what is expressed as "ours" or "yours." Hence, it is not very helpful to construct a general association of moral (or morally tamed) individuals and use it as a reference point for the rather ambitious project of reconciling cosmopolitan norms and local criteria of judgment.

Like Arendt, Benhabib shows her strong interest in federations at multiple levels of politics, but human rights norms clearly drive the type of federations Benhabib has in mind. In her view, the new international order, characterized as a human rights regime, is not "a smooth "command structure" because individuals interpret the "jurisgenerative" meanings of human rights standards in their actual lives (2009: 696). This discursive process can empower citizens in democracies. On this basis, Benhabib charges critics of human rights (e.g. “democratic sovereigntists") with ignoring the complex process through which cosmopolitan norms interact with the will formation of democratic peoples. As Benhabib perceives it, this ought to be a strenuous process. But, if norms are cosmopolitan and supposed to apply anytime and everywhere, what is the real implication for human rights practice? Obviously, the citizens to be empowered by human rights norms already belong to particular states with their own laws and cultures. If advocacy groups such as global human rights NGOs encounter local norms and practices that are not easily compatible with human rights, then how will their conviction that human rights must be "cosmopolitan" norms help them engage in a strenuous dialogue regarding those sources of local differences? Regardless of her intent, Benhabib's cosmopolitan federalism possesses a danger that could be open to the charge of imperialism.

Compared to Benhabib, Cohen is more cautious about the utility of human rights in the international context. In her view, conditioning membership and equality in a society of sovereign states according to the Rawlsian kind of "decency" approves the discourse of “outlaw states" (2008: 586). Cohen thinks this approach increases the possibility of violating 
a requirement of international law: the equality of all states. Invoking a series of recent “humanitarian" wars conducted by major Western states, Cohen (2008: 586) asks, "Wouldn't suspension of the sovereignty argument when rights to individual dissent, free expression, appeal, and the requirement of public justification of policy are violated amount to a green light to intervene against any authoritarian regime militarily?” For Benhabib (2009: 698[n30]), who is more concerned about the moral import of human rights discourse than its political function, Cohen's approach "put[s] the cart before the horse." But, for Cohen, the political consequences of human rights are an inseparable part of constructing an adequate conception of human rights. Reflecting this concern, she raises the threshold of the suspension of sovereignty by limiting it to cases of mass extermination and expulsion. This shift of focus from a positive list of individual rights to the radical violation of membership helps to reduce the problem that comes from favoring a particular type of political community on the basis of decency (Cohen, 2008: 588).

Cohen's "functional" conception of human rights as the equality of sovereign states also appears in her communitarian version of federalism, "constitutional pluralism" (2012: 6676). In agreement with legal pluralism, Cohen's constitutional pluralism affirms and promotes the idea that different constitutional orders exist in world politics. But, Cohen (2012: 70) also adds that pluralism can take the form of "a complex of political communities within an overarching political association of communities each of which has its own legal order of constitutional quality." Contra conventional realism, Cohen (2012: 73) argues that the absence of central authority in international politics does not necessarily lead to a vicious cycle of conflict and competition. Instead, it can "lead to reflexivity, communication, and cooperation and it need not end in fragmentation of either legal system, given sufficient commitment to a 
common enterprise, i.e. to the overarching political community created by member states and peoples."

Cohen (2008: 593) treats her sceptics as Schmittian realists who fail to see that "sovereignty is a normative and legal category, not only a fact of power." Her point is that although states may violate the principle of sovereign equality, they also constitute a legal mechanism that can regulate their conflict and cooperation. This verdict on state sovereignty may be empirically contested, but what concerns us here is the internal effect of this approach, that is, the intra-state demand of state agency. Cohen (2012: 135) identifies the situation in which citizens' individual agency is significantly reduced as a Schmittian one where "the decision over friend and enemy, internal and external, [is made] by a unitary people willing its political existence, its way of life, and deciding to maintain its homogeneity in the political sphere." Cohen wants to ensure that constitutional pluralism abandons Schmitt's existential conception of sovereignty.

But, even when we discard this worst-case scenario, there is no reason to believe that the problem associated with security competition would completely disappear in constitutional pluralism - a communitarian variant of federalism - because the latter in effect acknowledges the presence of different (often irreconcilable) orders in international politics. Cohen does not deny the possibility of international conflict rooted in such differences. Her argument is that sovereignty can remain the legal principle of sovereign equality among states. Yet, for Cohen (2012: 73), this comes with the qualification that there be "sufficient commitment to a common enterprise, i.e. to the overarching political community created by member states and peoples." The precondition of sufficient commitment to a common enterprise implies that without it, sovereignty would not remain a legal principle but could develop into "a fact of power." If this occurs, then we are essentially back in the familiar situation of state security 
competition, which in turn increases the danger of the illiberal condition in which individual citizens are deprived of their political agency under the so-called "security state."

Benhabib's and Cohen's approaches only confirm the difficulty of finding a middle way in international discourse. Both authors' common interest in federalism manifests in their desires to establish a middle ground for international politics. Yet, their other concerns, such as universal human rights or sovereign states, tend to prevail over the complex and dynamic aspects of state agency, which Arendt might have wanted to preserve. Thus, Benhabib's cosmopolitan federalism draws closer to deserving the charge of imperialism as it becomes more lenient toward the misuse of human rights discourse. Cohen's communitarian version of federalism, though it attends to the political function of human rights, at times entertains a rather unrealistic idea of sovereignty. Indeed, sovereignty is often more than a legal principle of sovereign equality. Cohen's constitutional pluralism, although it rightly promotes international equality and tolerance, tends to underrate the risk associated with having a sovereign nation or state-a danger that frequently manifests in the form of nationalism or authoritarianism. Arendt herself thinks we can prevent such a danger only with the presence of agonistic citizens devoted to public matters and through the delegation process at multiple levels of politics, conditions far from sovereign statism.

\section{The promise of international federalism}

The two variants of federalism are not separable from the contemporary context of politics in which the gap between the intra-state and inter-state demands of equality has increasingly grown. As Chris Brown (2013: 211-214) sensibly points out, the world has been polarized into two forms of international discourse that emphasize either anti-authoritarianism or antiimperialism. Cosmopolitanism received particular attention in the decade following the end of 
Cold War. Human rights activism became conjoined with anti-authoritarianism and took the form of humanitarian intervention in "immature" or "failed" countries in the 1990s. However, the United States' function as the only superpower in the post-Cold War era soon led to a growing concern about American hegemony. The voices against American power grew especially loud in the debate over the Iraq War, which attested to the emergence of antiimperialism as a major aspect of contemporary international discourse. With the growing gap between anti-authoritarianism and anti-imperialism, it has become common to see those who accentuate anti-imperialism be somewhat lenient toward authoritarian regimes, while advocates of anti-authoritarianism end up tacitly supporting the use of American/Western power for their cause.

Arendt's thoughts are particularly relevant in this context. In her thinking, we find insight directing our attention to the dual effect the post-Cold War development has had on international discourse. This development not only motivates the proponents of antiauthoritarianism and anti-imperialism to exaggerate the difference between these claims against inequality but also provides us with the opportunity to see the fundamental complexity that lies in pursuing a middle-ground discourse in international politics.

Arendt's thinking identifies two demands of equality (which are essential for maintaining state agency) and calls for their balance. This major aspect of her thoughts is particularly evident in her reflections on council-based federalism, demonstrating her equal disagreement with world government and international anarchy. Arendt finds a fundamental problem with the sovereign state system and looks for an alternative model. Contra liberal scholars, however, she advocates for international pluralism and considers federalism the best way to foster it. Yet, Arendt balances her argument for anti-imperialism with her deep concern about the rise of a sovereign dictator enforcing arbitrary decisions. Her emphasis on 
participatory politics at the grassroots level evinces her awareness of the danger of authoritarianism and her firm belief that we can protect ourselves from tyranny only when we actively deliberate public issues as diverse equals. In these regards, both intra-state and interstate equality receive due respect in Arendt's thoughts.

But, although Arendt does not view pursuing both anti-authoritarianism and antiimperialism as contradictory, as some of the realist and communitarian thinkers argue, she hardly thinks the goals of intra-state and inter-state equality are fully reconcilable in politics. To be sure, as noted, Arendt's call for federalism emerges from an endeavor to balance intrastate equality (against authoritarianism) and inter-state equality (against imperialism). One clear result of this line of thinking is her suggestion of "a world-wide federated structure," which she further details when delving into the council model, especially how the councils form a complex system of coordination at multiple layers of politics and function as "spaces of freedom" to incorporate new voices for change into the existing arrangements of political/legal judgment (1968: 93, 2006: 256). This integrative feature of Arendtian political community renders it far from self-contained. Indeed, as a case for international politics, Arendt's council-based federalism strongly suggests that severe competition for security among states is not an inevitable outcome. Arendt's federalism envisions and considers the condition under which states coexist while holding their own orders, each of which goes through gradual modifications as disruptive voices and opinions calling for change are integrated into the resulting amendments of the constitution.

Even so-and this is crucial-Arendt's federalism remains inconclusive regarding state agency. Her objection to a world state comes with her wholehearted endorsement of international plurality, the condition that fosters the pluralistic orders in international politics. For Arendt, this condition is necessary for creating an international authority in between states, 
which in turn would prevent any rise of global hegemony. Here, though, we face this question: Who is the constitutive actor in that pluralist order of international politics? If the main representatives on the diplomatic scene are states, the ensuing issue is that of representation, often dubbed the "part and whole" problem. We can hardly predict that individuals and groups will always find their interests compatible with states' collective interests. However, treating individuals as the main representative actors in the international scene does not entirely express Arendt's thinking either. For an effective diplomacy, Arendt would agree that collective entities such as states are essential —in fact, in her statements about resisting world tyranny, states constituting pluralistic orders for international politics receive core attention. She also asserts that states need to secure certain independent dimensions for themselves to help free politics avoid constant popular turbulence and foster stability and continuity for achieving human greatness and flourishing.

Arendt's international federalism oscillates between these two aspects of state agency. On one hand, through the council model, Arendt's federalism reduces the gap between the claims of inter-state equality against imperialism and intra-state equality against authoritarianism. On the other, Arendt's thinking suggests that at the most fundamental level, these demands are not fully reconcilable. A clear symptom of this dual aspect of Arendt's thinking is her ambiguity regarding the relationship between the higher and lower levels of councils. We thus confirm that the state in Arendt's council-based federalism is torn between the demands of representing its people and being a competent diplomatic partner to other state actors.

Should we consider this ambiguity a weakness in Arendt's thoughts? We have discussed how some contemporary Arendt studies and cosmopolitan and communitarian variants of federalism fail to see the real meaning behind such ambiguity in Arendt's 
international federalism. For a federalist stream of international security theory, too, pursuing an Arendtian federation cannot be viewed favorably. For example, in Daniel Deudney's (2007) global federalism, the complex and dynamic aspects of state agency Arendt's federalism maintains do not figure much. Relying on the change in material contexts produced by the development of weapons of mass destruction and affirming the efficacy of the early American model of federal power restraints, the security-oriented federalism, a la Deudney, envisions a Philadelphian moment on a global scale to establish a world constitution on which all states are federated (Blachford, 2019: 35-39).

This security variant of federalism that focuses on material capabilities may dispel the Arendtian ambiguity and entertain a more promising global federation. However, it faces the question of whether international cooperation driven by a fear of mutual destruction can be considered authentically political. For Arendt, true politics happens when people act together for freedom and find joy in the public activity itself. A flashy moment of unity formed by an enormous fear of destruction is qualitatively different from what Arendt (1998: 57) calls "sameness in utter diversity," the condition that diverse equals fulfill through a strenuous process of public debate and deliberation. Federal arrangements envisioned by this view of the political are highly contingent because their fundamental base is the public worlds "born of the specific actions and agreements of particular men and dependent on continuing support for their survival" (Canovan, 1992: 248). Beyond the philosophical/theoretical level, Arendt's political thought greatly appreciates the contingent aspect of public worlds. It thus differs from approaches that offer a blueprint for solving the contemporary problems of politics (even in the form of federalism).

Arendt's reflections on federalism make some specific issues less clear, leaving the task of clarification to actual citizens who deliberate about the future of their common spaces for 
freedom and revealing the complexity of those problems. Arendt intends to do so because for her, the task of balancing the two demands of international politics through federalism is not to reconcile them but to generate questions to reflect upon through her vision of free politics. Arendt offers us a distinctive model of free politics that views the two demands of equality as neither contradictory nor reconciliatory but rather as ideal types along a continuum—allowing us to explore a middle ground for international discourse with a clear acknowledgement of its precariousness. ${ }^{5}$ In the divisive context of contemporary politics, this approach draws timely attention to the importance of balancing the claims of intra-state and inter-state equality beyond rhetorical exaggeration while helping us see the fundamental complexity relating to state agency we inevitably encounter when pursuing international federalism.

Arendt's council-based federalism can best be characterized as a modest exploration of a middle way of politics that acknowledges the contingency of politics and the limits of theorizing about politics. This approach differs not only from a realism that takes for granted the presence of self-contained political communities in international politics and from a cosmopolitanism that underrates the danger of world tyranny but also from some of the alternative approaches to international relations that confuse theoretical possibilities with practical politics. To meet the two competing demands of equality, Arendt never ceases to emphasize the role of actual political actors, urging them to consider what they gain and lose from attending to each side of free politics. Indeed, her federalism offers important principles, if not an ultimate solution, that political actors in either domestic or international scenes should consider when judging the future of their common spaces for freedom. As such, it

\footnotetext{
5 On Arendt's complex usage of the Weberian term, “ideal type," see Arendt (1973: 361-362[n57], 1979: 329); Baehr (2010: 26); Klusmeyer (2009: 35).
} 
facilitates politicizing federation by showing both its merit as a mode of balancing essential demands for free politics and its fundamental complexity. This much-needed sensitivity to international discourse is what Arendt's federalism promises us. 


\section{References}

Arato A and Cohen J (2010) Banishing the sovereign? Internal and external sovereignty in Arendt. In: Benhabib S, Tsao R, and Verovšek P (eds) Politics in Dark Times: Encounter with Hannah Arendt. Cambridge: Cambridge University Press, pp. 137-171.

Arendt H (1958) Totalitarian imperialism: Reflections on the Hungarian Revolution. Journal of Politics 201(1): 5-43.

Arendt H (1968) Men in Dark. Times. New York: Harcourt.

Arendt H (1970) On Violence. New York: Harcourt.

Arendt H (1972) Crises of the Republic. New York: Harcourt.

Arendt H (1973) The Origins of Totalitarianism. New York: Harcourt.

Arendt H (1979) On Hannah Arendt. In: Hill M (ed.) Hannah Arendt: The Recovery of the Public World. New York: St Martin’s Press, pp. 301-339.

Arendt H (1993) Between Past and Future. New York: Penguin Books.

Arendt H (1994) Essays in Understanding, 1930-1954. New York: Harcourt.

Arendt H (1998) The Human Condition. Chicago: University of Chicago Press.

Arendt H (2006) On Revolution. New York: Penguin Books.

Arendt H (2007) The Jewish Writings. New York: Schocken Books.

Ashcroft C (2017) Jewishness and the problem of nationalism: A genealogy of Arendt's early political thought. Modern Intellectual History 14(2): 421-449.

Axtmann R (2006) Globality, plurality, and freedom: The Arendtian perspective. Review of International Studies 32(1): 93-117.

Baehr P (2010) Hannah Arendt, Totalitarianism, and the Social Sciences. Stanford: Stanford University Press. 
Barbour C (2014) The republican and the communist: Arendt reading Marx (reading Arendt). In: Habjan J and Whyte J (eds) Mis)readings of Marx in Continental Philosophy. New York: Palgrave, pp. 51-66.

Barder A and McCourt D (2010) Rethinking international History, theory and the event with Hannah Arendt. Journal of International Political Theory 6(2): 117-141.

Benhabib S (2004a) Reclaiming universalism: Negotiating republican self-determination and cosmopolitan norms. Available at: http://tannerlectures.utah.edu/_documents/a-toz/b/benhabib_2005.pdf (accessed January 2, 2020).

Benhabib S (2004b) The Rights of Others: Aliens, Residents, and Citizens. Cambridge: Cambridge University Press.

Benhabib S (2006) Another Cosmopolitanism. Oxford: Oxford University Press.

Benhabib S (2007) Democratic exclusions and democratic iterations: Dilemmas of "just membership" and prospects of cosmopolitan federalism. European Journal of Political Theory 6(4): 445-462.

Benhabib S (2009) Claiming rights across borders: International human rights and democratic sovereignty. American Political Science Review 103(4): 691-704.

Benhabib S (2014) Defending a cosmopolitanism without illusions. Critical Review of International Social and Political Philosophy 17(6): 697-715.

Blachford K (2019) Republicanism within IR: A history of liberty and empire. Millennium: Journal of International Studies 48(1): 25-44.

Brown C (2013) Authoritarianism, anti-imperialism, and intervention: The precariousness of the middle ground." In: Navari C (ed.) Ethical Reasoning in International Affairs: Arguments from the Middle Ground. New York: Palgrave, pp. 203-221. 
Canovan M (1983) Arendt, Rousseau, and human plurality in politics. Journal of Politics 45(2): 286-302.

Canovan M (1992) Hannah Arendt: A Reinterpretation of Her Political Thought. Cambridge: Cambridge University Press.

Canovan M (1996) Hannah Arendt as a conservative thinker. In: May L and Kohn J (eds) Hannah Arendt: Twenty Years Later, Cambridge: The MIT Press, pp. 11-32.

Cohen J (2008) Rethinking human rights, democracy, and sovereignty in the age of globalization. Political Theory 36(4): 578-606.

Cohen J (2012) Globalization and Sovereignty: Rethinking Legality, Legitimacy, and Constitutionalism. Cambridge: Cambridge University Press.

Deudney D (1995) The Philadelphia System: Sovereignty, arms control, and the balance of power in the American states-union, circa 1787-1861. International Organization 49(2): $191-228$.

Deudney D (2007) Bounding Power: Republican Security Theory from the Polis to the Global Village. Princeton: Princeton University Press.

Hayden P (2009) Political Evil in a Global Age: Hannah Arendt and International Theory. London: Routledge.

Hueglin T and Fenna A (2005) Comparative Federalism: A Systematic Inquiry. Toronto: University of Toronto Press.

Hyvönen A (2016) Political action beyond resistance: Arendt and "revolutionary spirit" in Egypt. Redescriptions 19(2): 191-213.

Jackson P (2004) Hegel's house of "people are states too." Review of International Studies 30(2): 281-287. 
Kaldor M (2013) Reconstructing global security for the twenty-first century. In: Kaldor M and Stiglitz J (eds) The Quest for Security: Protection without Protectionism and the Challenge of Global Governance. New York: Columbia University Press, pp. 117-142.

Kalyvas A (2008) Democracy and the Politics of the Extraordinary: Max Weber, Carl Schmitt, and Hannah Arendt. Cambridge: Cambridge University Press.

Klusmeyer D (2009) Hannah Arendt's case for federalism. Publius: The Journal of Federalism 40(1): 31-58.

Lang A (2002) Agency and Ethics: The Politics of Military Intervention. Albany: State University Press of New York.

Lang A (2005) Between international politics and international ethics. In: Lang A and Williams J (eds) Hannah Arendt and International Relations: Readings across the Lines. New York: Palgrave, 2005, pp. 221-232.

Lang A (2013) Global constitutionalism as a middle-ground ethic. In: Navari C (ed.) Ethical Reasoning in International Affairs: Arguments from the Middle Ground. New York: Palgrave, pp. 106-126.

Lederman S (2019) Hannah Arendt and Participatory Democracy. New York: Palgrave.

Lee S (2020) The lex of the earth? Arendt's critique of Roman law. Journal of International Political Theory. Epub ahead of print 2 January 2020. DOI: 10.1177/1755088219898237.

Lee S (2020) Building communities of peace: Arendtian realism and peacebuilding. Polity. Epub ahead of print 23 October 2020. DOI: 10.1086/711647.

Lindahl H (2009) In Between: Immigration, distributive justice, and political dialogue. Contemporary Political Theory 8(4): 415-434.

Miller D (2016) How "realistic" should global political theory be? Some reflections on the debate so far. Journal of International Political Theory 12(2): 217-233. 
Muldoon J (2016) The origins of Hannah Arendt's council system. History of Political Thought 37(4): 761-789.

Neumann I (2004) Beware of organicism: The narrative self of the state. Review of International Studies 30(2): 259-267.

Owens P (2007) Between W ar and Politics: International Relations and the Thought of Hannah Arendt. Oxford: Oxford University Press.

Rengger N and Thirkell-White T (2007) Introduction. In: Rengger N and Thirkell-White T (eds) Critical International Relations Theory after 25 Years. Cambridge: Cambridge University Press, pp. 3-24.

Rensmann L (2019) Rethinking European democracy after its legitimacy crisis: On Hannah Arendt and the European Union. Journal of European Studies 49(3-4): 1-22.

Ringmar E (1996) On the ontological status of the state. European Journal of International Relations 2(4): 439-466.

Selinger W (2016) The politics of Arendtian historiography: European federation and The Origins of Totalitarianism. Modern Intellectual History 13(2): 417-446.

Smith J (2007) Social Movements for Global Democracy. Baltimore: Johns Hopkins University Press. Verovšek P (2014) Unexpected support for European integration: Memory, rupture, and totalitarianism in Arendt's political theory. The Review of Politics 76(3): 389-413.

Villa D (1992) Postmodernism and the public sphere. American Political Science Review 86(3): $712-721$.

Villa D (2008) Public Freedom. Princeton: Princeton University Press.

Volk C (2015) Arendtian Constitutionalism: Law, Politics and the Order of Freedom. Oxford: Hart.

Waldron J (2000) Arendt's constitutional politics. In: Villa D (ed.) The Cambridge Companion to Hannah Arendt, Cambridge: Cambridge University Press, pp. 201-219. 
Waltz K (1979). Theory of International Politics. Reading: Addison-Wesley.

Weber C (1998) Performative states. Millennium: Journal of International Studies 27(1): 77-95.

Weisman T (2013) Hannah Arendt and Karl Marx: On Totalitarianism and the Tradition of Western Political Thought. Lanham: Lexington Books.

Wendt A (2004) The state as person in international theory. Review of International Studies 30(2): 289-316.

Wight C (2004) State agency: Social action without human activity? Review of International Studies 30(2): 269-280.

Williams J (2005) Introduction. In: In: Lang A and Williams J (eds) Hannah Arendt and International Relations: Readings across the Lines. New York: Palgrave, 2005, pp. 1-26. 